\title{
Typology of Glazed Ceramics of the Kazan Khanate and Analysis of Its Element Composition
}

\author{
Airat G. Sitdikov ${ }^{1,2}$ \& Rezida Kh. Khramchenkova ${ }^{1,2}$ \\ ${ }^{1}$ Kazan (Volga Region) Federal University, Kazan, Russia \\ ${ }^{2}$ Institute of Archaeology named after A. Kh. Khalikov of Academy of Sciences of the Republic of Tatarstan, \\ Kazan, Russia \\ Correspondence: Rezida Khramchenkova, Kazan (Volga Region) Federal University, 420008, Kazan, \\ Kremlyovskaya Street, 18, Russia. E-mail: rezidahram@mail.ru
}

Received: June 15, 2015 Accepted: June 24, 2015 Online Published: June 30, 2015

doi:10.5539/jsd.v8n7p234 URL: http://dx.doi.org/10.5539/jsd.v8n7p234

\begin{abstract}
Studying on archaeological material the history of the Kazan Kremlin which was included in the list of UNESCO in 2000 is an actual problem because of the limited written sources remained. The aim of the work is to study the features of trade and craft traditions of the late Middle Ages Kazan on the example of ceramic artifacts. The authors applied a complex of analytic methods which included morphology and element composition of glaze: samples of glazed ceramics with green, brown and blue glaze. The chemical composition of glaze of three ceramics samples was determined in the article by two methods. They are the emission spectroscopy and the method of electron microscopy. The good comparability of analytical data of two independent methods is shown in the article. Both advantages and disadvantages of each type of the analysis are given. The data on a chemical composition in the article show that two samples of the glaze is lead, the third sample is lead-tin with an addition of ash (that is sodium and potassium). Results of the article revealed an optimal range of analytical procedures for the studying of glazed ceramics and may be useful as methodical material for archeometric researches.
\end{abstract}

Keywords: archaeological ceramics, glaze, chemical composition, X-ray, emission spectroscopy, Kazan Kremlin

\section{Introduction}

Expressive archeological findings of medieval archaeological monuments are samples of the glazed vessels possessing considerable potential. Studying this type of artifacts gives information about time and place of production of the revealed vessels that allows determining the areas of commercial relations and also in some cases to establish the level and features of production technologies development.

Archeologists' researches at the territory of Kazan Kremlin in the 1990s gave diverse in its composition glazed ceramics of the Kazan Khanate era. The most part of it, connected with the eastern import, by the state of 2001 was analysed in special research by V.Yu. Koval' (Koval', 2006). He examined 166 fragments of ceramics from the layers formed from XI to the XVII centuries. A group of glazed ceramics occurring predominantly from the late period of the Golden Horde and beddings of the Kazan Khanate was out of this research (Sitdikov, 2006). This category of glazed ware consists of 107 fragments found in twenty one excavations during the period from 1994 to 2001. Reports and works by N. F. Kalinin (1953, 1954 and 1958), L.S. Shavokhin (1977, 1981) and A.Kh.Khalikov (1977, 1983 and 1989) have the description of similar findings from beddings of the Golden Horde and the Kazan Khanate. The similar ware is also known at other monuments of this time in the Volga-Kama region. A significant amount of it was available in collections of the Iske-Kazansky memorial estate from excavations of the Kamayevsky ancient settlement and Russkourmatsky settlement, but access to materials for a number of reasons is closed by now (Kokorina, 1990).

In recent years researchers actively study a chemical composition of ceramic findings (Fernandez-Ruiz, 2007; Griffits, 1999; Ionescu et al., 2011; Nuretdinova, Hramchenkova, 2011; Bakhmatova et al., 2013). These data allow to define both features of a compounding and the specifity of the production technology relating to certain ceramic schools (Khramchenkova, 2013). In some cases these data can identify an artifact origin (Hramchenkova, 2011). Data of chemical composition researches of glaze of 32 ceramics fragments from excavations of the 
Kazan Kremlin are presented in the work by Khramchenkova and Sitdikov (2014). Three samples whose selection was defined by a glaze color originality of the main archaeological ceramics types were chosen in this work for identification of an optimal analytical method of studying the glaze features. Comparison of research results of artifacts by the method of electron microscopy with the microprobe X-ray-fluorescent analyzer and method of the emission spectroscopy was carried out for this purpose.

\section{Materials and Methods}

\subsection{Morphological Analysis}

According to the typology, samples of the studied glazed ceramics can be divided into two groups. The first group includes red ware with blue glaze; the second group includes white and red ware with green and brown glaze.

The first group of glazed ceramics (fig. 1) includes 14 fragments with monochrome blue glaze of undecorated red ware with white underglaze engobe. In some cases an internal surface at the level of a chaplet with sags of water is engobed. Fragments belong to jugs of a pear-shaped form, by small size, with the flat bottom which is cut off by a knife. There are fragments of round-shaped handles in the section. The ware is made of red clay without visible impurity. During the burning process the dough is overheated and has a brownish-gray hue. There are drag marks in internal part; the internal surface has prominent horizontal deepenings. The reconstructed height of jugs does not exceed $20-25 \mathrm{~cm}$. Analogies of such ceramics are not known. 9 findings stratigraphically are attached to layers of the XV-XVI centuries, 5 fragments are from beddings of the XIV century. The sample № 2 (348) (fig. 2, 2) was taken to an analytical series.
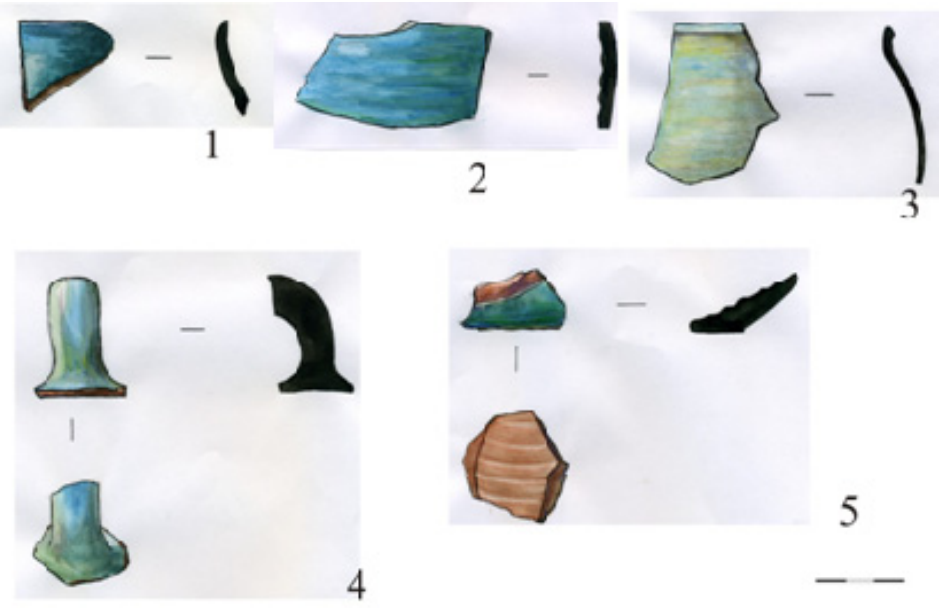

4
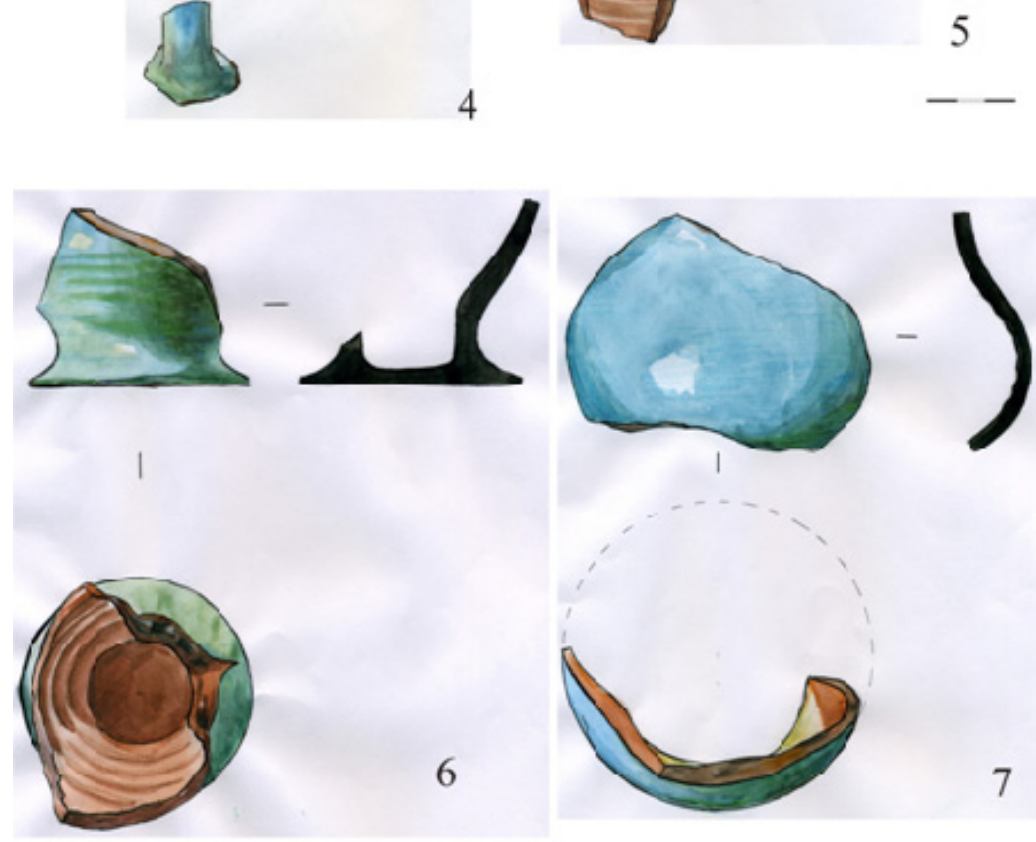

Figure 1. Red ware with blue glaze

1 - KK96-VII/274; 2 - KK98-X/348; 3 - KK01-XLIII-A/393; 4 - KK01-XLIII-A/578; 5 - KK00-XXXIV/1983; 6 - KK01-XLVIII/478; 7 - KK00-XXXIV/2838. 
The second group makes the most part of glazed ceramics. It is the decorated monochrome semi-majolica with green and brown glaze with a cut-in ornament on a white or red ware with engobe in number of 93 fragments. We distinguish two types based on the test features of ceramics:

Type 1. White ware with green and brown glaze (fig. 2).

It is represented in the studied collection by 70 samples and is divided into two variations.

White ware with green glaze.

This type includes the most part of samples (63 fragments) from jugs, kumgan and lids from beige-white clay with inclusions of reddish chamotte, perhaps, fragments of pounded red ware or without visible inclusions in general. Jugs and kumgans have the chaplet shape as the roller passing into a neck by the form of a bell. Body has a pear-shaped form and a heel shaped bottom. The surface of the ware and the bottom part is plentifully covered with translucent glaze. There is the saturated cut-in ornament on the outer surface. The engraved pattern is made before putting engobe and presented in the form of parallel lines, prints of a small seed-shaped stamp on the vessels body and on lids surface, the short parallel and crossed lines, circles, small tear-shaped prints of a stamp with a point in the lower part, stamped drawing in a square in the form of a bird. There is a belt in the middle of a body on a number of samples ornamented with a small stamp or in the form of the small roller.

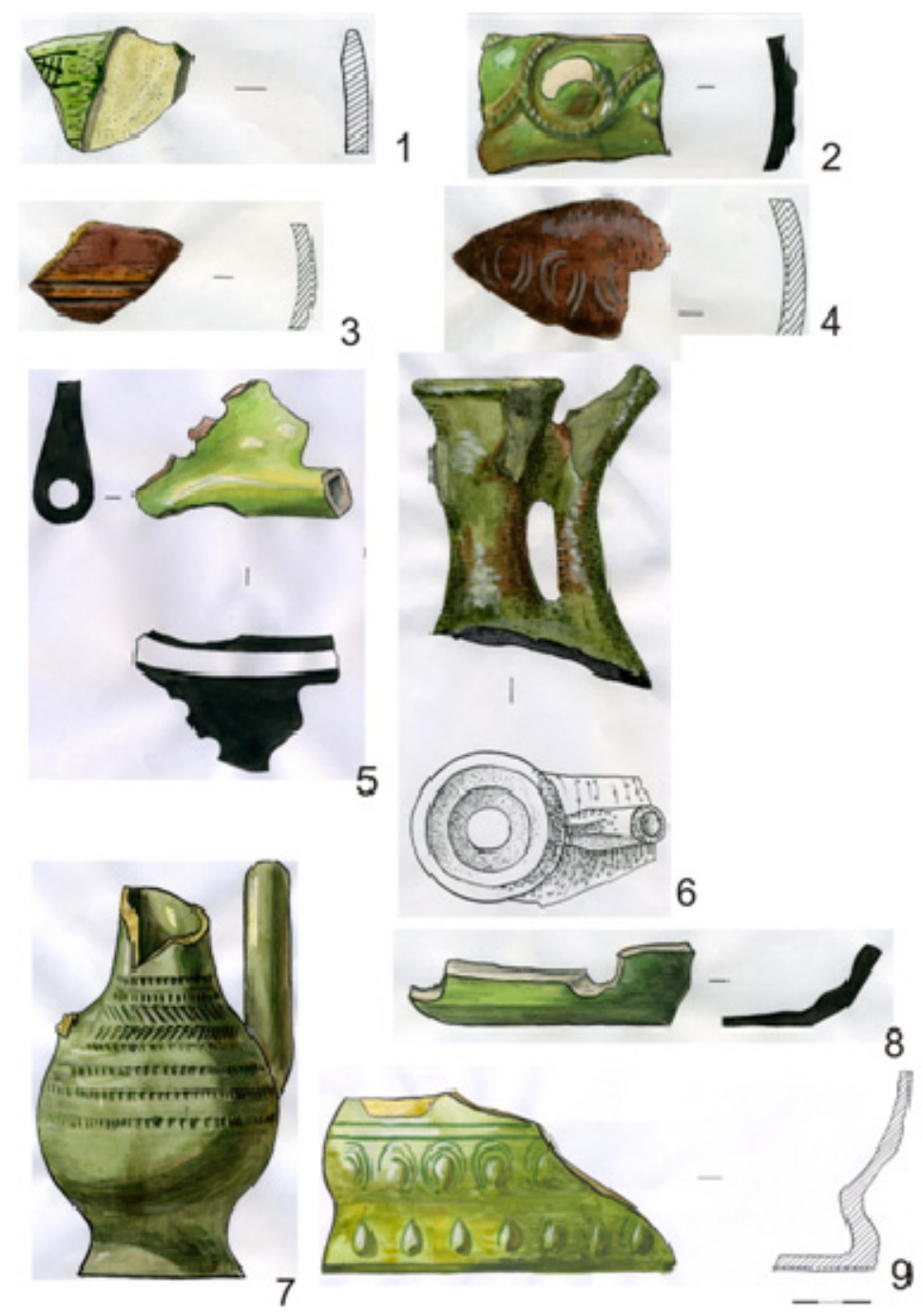

Figure 2. White ware with green and brown glaze

1 - КК01-XLII/556; 2 - КК95-III/19; 3 - КК94-IIб/1386; 4 - KK01-XLIII-A/134; 5 - KK98-X/266; 6 KK01-XLVIII/1; 7 - KK00-XXXIV/1501; 8 - KK00-XXXIV/185; 9 - KK01-XLIX/60. 
The majority of samples are from XV-XVI centuries. - 28

The sample No. 1 (267) corresponds to this ceramics in analytical researches (Sitdikov, 2006, fig. 148 №2) which belongs to lead type.

Stratigraphically the prevailing part of samples comes from the horizons of the XV-XVI centuries (28 fragments), one sample is from a layer of the XIV century, and 19 fragments are not attached or found in the top layers.

White ware with brown glaze

There are 7 samples of the jugs coming from the layers formed in the second half of the XV - the first half of the XVI century. This type of ceramics is presented in the chemical analysis by a sample № 3 (1386).

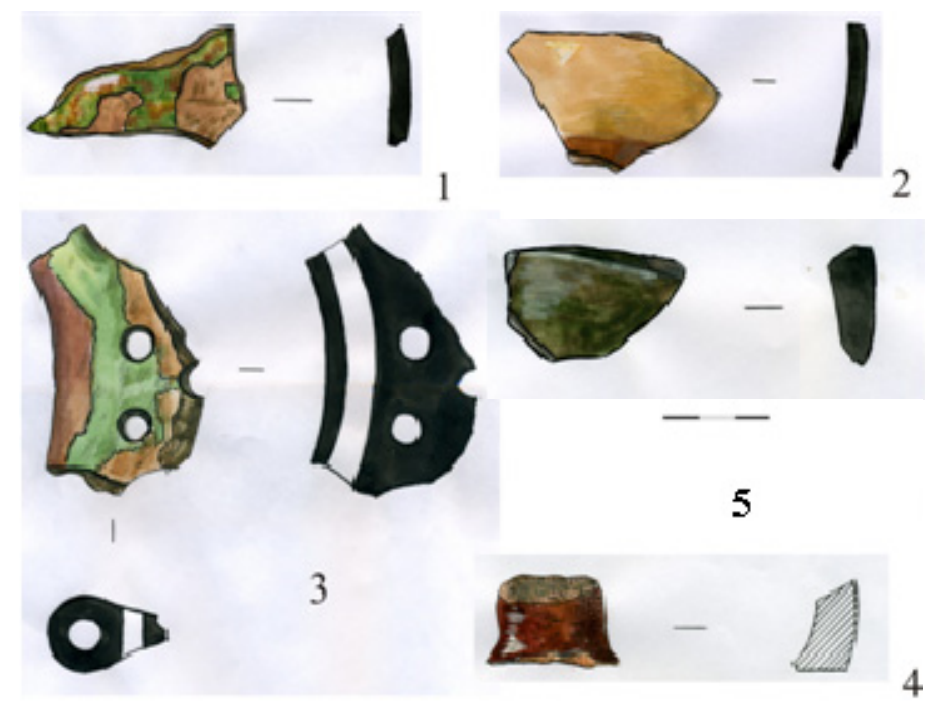

Figure 3. Red ware with green and brown glaze

1 - KK01-XLIII-Б/268; 2 - KK00-XXXIV/2553; 3 - KK98-XXII/42; 4 - KK-94/1736, 5 - KK98-X/267

The total number of samples is 23 fragments.

\section{Type 1. White ware with green and brown glaze (fig.3).}

It is represented in the studied collection by 70 samples and is divided into two types according to the glaze colour.

\section{Red ware with green glaze.}

It is presented by 16 samples of jugs and kumgans with fat clay. Forms of vessels, engraving and other elements of decorating are similar to the white ware. Stratigraphically it comes from the horizons of the second half of the $\mathrm{XV}$ - the first half of the XVI century; seven fragments come from later layers or have no stratigrafic reference. The similar ceramics is also recorded in the Russian-Urmastky settlement and the Kamayevsky ancient settlement. Existence of red ware or ceramics with a pinkish shade is also noted at these monuments. N. A. Kokorina and R.G.Fakhrutdinov connect its occurance with penetration into Zakamye of the Oguzo-kypchakski groups of the Lower Volga population. They refer it to the early Kazan ceramics and note its occurance in the second half of the XV century that does not contradict to the materials of the Kazan Kremlin.

\section{Red ware with brown glaze}

The total number of fragments of this category is 7. Characteristics of form and technologies of production do not differ from the above described groups of semi-majolica except for a sample with underglaze painting. 3 samples come from beddings of the second half of the XV - the first half of the XVI century stratigraphically. One fragment is revealed from beddings of the XIV century and another one comes from the derived beddings.

In general all of these groups of white and red ware from the Kamayevsky ancient settlement and Russian-Urmatsky settlement are considered as one type of ceramics which also has analogues in production of 
unglazed ware. These monuments are connected with potter's horns and necessary devices for the production of pottery. The chart of a ratio of various types of ceramics is given in fig. 4 .

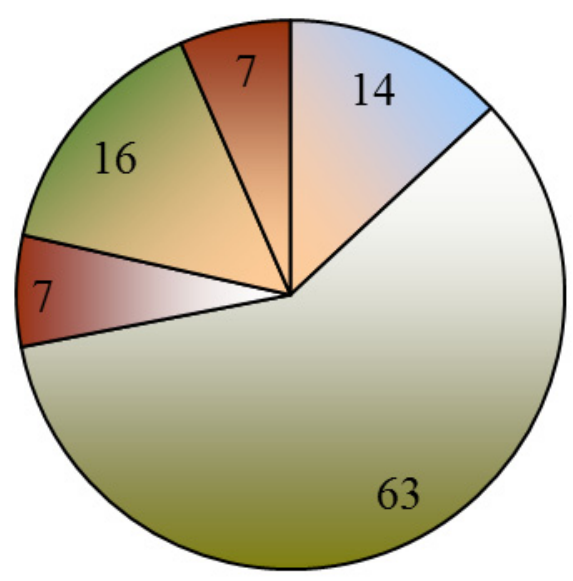

\section{$\square 1 \square 2 \quad \square 3 \quad \square 4 \quad \square 5$}

Figure 4. The chart of a ratio of various types of ceramics

1 - red ware with blue glaze; 2 - white ware with green glaze; 3 - white ware with brown glaze, red ware with green glaze, red ware with brown glaze

\subsection{Research of a Chemical Composition}

It was decided to choose the optimal analytical method for the determination of a chemical composition in the case of three samples for a more detailed studying of various groups of ceramics. For this purpose it was taken by one fragment from each group of glazed ceramics from excavations of the Kazan Kremlin and the element composition of glaze was determined. Quantitative results of these researches are given in tables 1-3. Various analytical methods were used during researches. Method of electron microscopy with the microprobe X-ray fluorescence analyzer and method of the emission spectroscopy were taken as two main methods for determination of element structure. Restriction of the study group by three samples is due to a high cost of one of the analysis methods. However, this quantity of samples was quite enough for comparison and the overall picture received by various methods.

X-ray phase analysis of a surface of the analyzed samples was carried out at the Central research institute of nonmetallic minerals (Kazan) in order to verify the presence of unfused components in glaze used in its production. The results of researches showed that all samples of glaze consist of almost fully amorphized substance, i.e. all the components of initial glaze passed into a glassy phase.

The studied samples were sent to the electron microscopy laboratory of Physics and Technology Institute of Kazan affiliation of Russian Academy of Sciences for initial determination of element structure. It is known that trace amount of the studied sample is enough for research using this method. The analysis of a surface of glazed ceramics was carried out by the method of scanning electron microscopy (SEM with the microprobe X-ray spectral analysis). Researches were conducted on an electronic microscope EVO-50XVP, combined with a spectrometer of power dispersion INCA-350. Measurements were taken at the low-vacuum mode, the accelerating voltage was $20 \mathrm{keV}$, with pressure in the microscope camera of 30 pascal. The studied samples were different-sized. The maximum section of determination was $0,3 \times 0,1 \mathrm{~mm}^{2}$ (fig. 5). Figure 6 shows areas and their results are given in table 1 in the second column. The areas of scanning are marked with rectangles. As shown in 
the table, the most reliable data on the standard sample were received from the analysis of the maximum surface.

\section{Results}

\subsection{Analytical Data}

Table 1 shows data from the maximum sections of determination. Results of the analysis of a standard sample of glass are given in the 4th column of the table, the standardized content of elements is italicized. According to the results, it is impossible to call a method of the scanning electron microscopy rather sensitive and reliable. So, antimony, tin and lead were not determined at all, and copper was found only in general, i.e. in the maximum section. It is possible that analysis accuracy is influenced in this case by the value of the incoming signal. In this regard, the elements presented in a standard sample by small content such as $\mathrm{Co}, \mathrm{Ag}, \mathrm{B}, \mathrm{Ba}, \mathrm{Bi}, \mathrm{Ni}, \mathrm{Zn}$ were not determined. Results of the quantitative spectral analysis which is carried out in the scientific and restoration methods department of the archeology museum of the History Institute n.a. Sh. Mardzhani by Academy of Sciences of the Republic of Tatarstan are given in tables by italics.

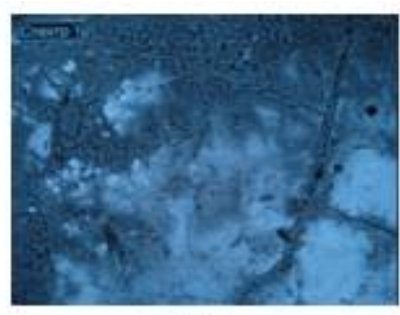

a

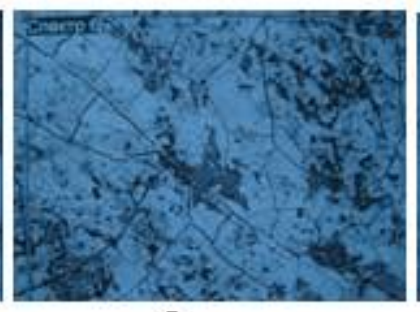

6

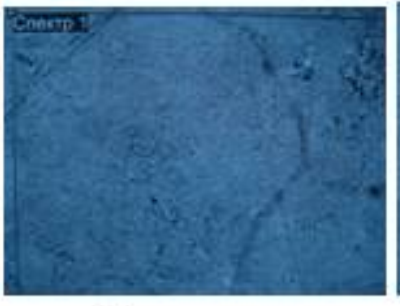

B

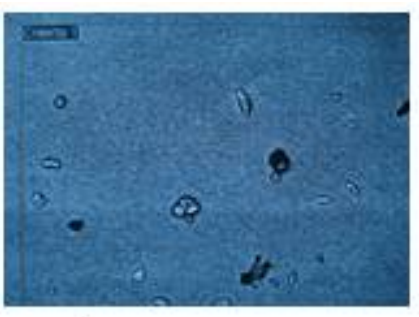

$\Gamma$

Figure 5. Photographies of the analysis of the maximum surface; a - sample 267, б - образец 334, в - sample 1386, $\Gamma$ - standard; 10000 -fold increase

Table 1. Element composition of the glaze of glazed ceramics determined by a microprobe method (SEM) and method of the emission spectral analysis (ESA) (concentration in \%)

\begin{tabular}{|c|c|c|c|c|c|c|c|c|c|c|c|c|}
\hline & \multicolumn{3}{|c|}{267} & \multicolumn{3}{|c|}{343} & \multicolumn{3}{|c|}{1386} & \multicolumn{3}{|c|}{ Korning D } \\
\hline & SEM & & ESA & SEM & & ESA & SEM & & ESA & SEM & & standard \\
\hline C & 10.80 & 6,15 & & 4.92 & 6,97 & & 5.69 & 12,09 & & & & \\
\hline $\mathbf{O}$ & 28.42 & 25,22 & & 48.67 & 50,85 & & 28.68 & 27,71 & & 46.83 & 47,77 & \\
\hline $\mathrm{Na}$ & 0.36 & 0,57 & 0,51 & 2.60 & 1,1 & 5,78 & & & 0,3 & 0.77 & 0,82 & 0,97 \\
\hline Mg & 0.31 & 0,31 & 0,27 & 1.47 & 2,3 & 1,72 & 0.37 & 0,22 & 0,37 & 2.12 & 2,07 & 2,49 \\
\hline Al & 1.99 & 0,77 & 2,11 & 3.08 & 4,14 & 3,05 & 0.85 & 1,14 & 2,3 & 2.53 & 2,52 & 2,91 \\
\hline $\mathbf{S i}$ & 6.28 & 1,84 & 20,85 & 21.8 & 23,3 & 26,43 & 9.08 & 8,2 & 19,97 & 24.93 & 24,87 & 25,7 \\
\hline $\mathbf{P}$ & 4.56 & 6,24 & 0,36 & 2.38 & 0,4 & 0,1 & 1.09 & 1,54 & 0,083 & 1.77 & 1,82 & 1,53 \\
\hline Cl & 1.37 & 2,27 & & 1.95 & 0,46 & & 0.76 & & & 0.26 & 0,16 & - \\
\hline $\mathbf{K}$ & 0.79 & 0,36 & 0,36 & 4.36 & 2,48 & 1,2 & 0.29 & & 0,21 & 9.48 & 9,16 & 10,0 \\
\hline $\mathrm{Ca}$ & 4.00 & 4,83 & 0,97 & 0.04 & 2,21 & 2,2 & 1.07 & 1,65 & 0,8 & 9.99 & 9,7 & 10,07 \\
\hline $\mathbf{F e}$ & 1.41 & 0,99 & 0,83 & 1.22 & 0,69 & 2,9 & 5.09 & 4,46 & 3,55 & 0.37 & 0,4 & 0,36 \\
\hline $\mathbf{P b}$ & 39.70 & 50,44 & 42,27 & 6.12 & 3,18 & 6,89 & 47.04 & 42,95 & 41,6 & & & 0,25 \\
\hline Sn & & & 0,2 & & & 6,55 & & & 0,007 & & & 0,15 \\
\hline $\mathrm{Cu}$ & & & 0,21 & 1.12 & 0,52 & 0,93 & & & 0,11 & 0.40 & & 0,33 \\
\hline Mn & & & 0,021 & 0,04 & & 0,06 & & & 0,013 & 0.39 & 0,42 & 0,43 \\
\hline $\mathbf{T i}$ & & & 0,11 & & & 0,32 & & & 0,15 & 0.16 & 0,19 & 0,23 \\
\hline $\mathbf{S b}$ & & & & & & & & & & & & 0,63 \\
\hline
\end{tabular}


The results of analyses from the $0,01 \times 0,01 \mathrm{~mm}^{2}$ area are given in the third column of table 1 for comparison. According to the results of analyses, significant difference of contents in determinations is observed, and some elements did not revealed at all (f.e. $\mathrm{Mn}$ is in a sample $267, \mathrm{~K}$ is in a sample $1386, \mathrm{Cu}$ is in the standard).

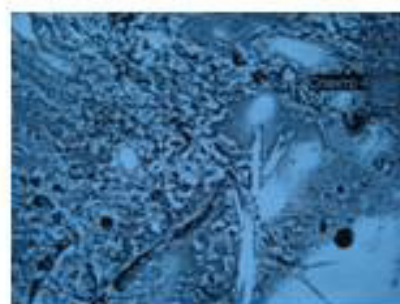

a

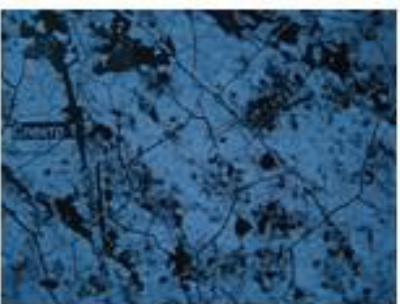

6

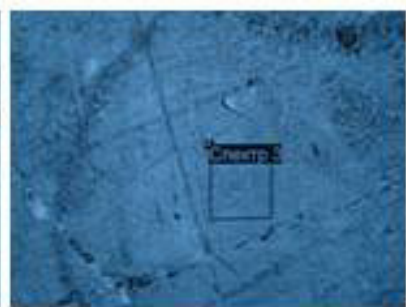

B

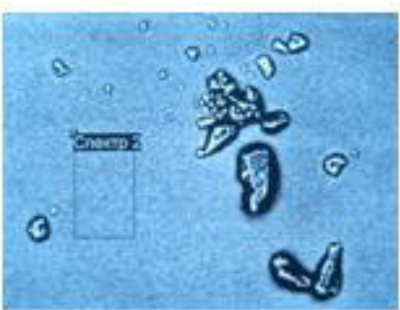

$\Gamma$

Figure 6. The areas of scanning are marked with rectangles; a - sample 267, 6 - sample 334, в - sample 1386, г - standard; 10000 -fold increase

From the table 1 it can be seen that the method of electron microscopy did not allow to determine in studied by us glaze important elements making so-called "basis" as Ti, $\mathrm{Mn}, \mathrm{Cu}, \mathrm{Pb}, \mathrm{Sn}$. Therefore, it was decided to analyze the studied glaze by the most informative method of the quantitative emission spectroscopy. Spectrographs for the analysis were received by evaporation of samples in an alternating-current arc (7-15A) on the diffraction spectrograph DFS-458. This spectrograph allows us to receive rather big set of the analyzed elements, i.e. more than 30. Interpretation of spectrographs was carried out on the microphotometer MF-2 with the subsequent processing on the standard computer program. Results of the analysis are given in tables 2 and 3.

Table 2. Concentration of basic elements and their oxides in \% determined by method of the emission spectroscopy

\begin{tabular}{rcrrrrrrrrrrrrr}
\hline & code & $\mathbf{C u O}$ & $\mathbf{M n O}$ & $\mathbf{P b O}$ & \multicolumn{1}{c}{$\mathbf{S n O}$} & $\mathbf{T i O}$ & $\mathbf{P}_{2} \mathbf{O}_{\mathbf{5}}$ & $\mathbf{C a O}$ & $\mathbf{F e}_{2} \mathbf{O 3}$ & $\mathbf{A l}_{2} \mathbf{O 3}$ & $\mathbf{K}_{\mathbf{2}} \mathbf{O}$ & $\mathbf{M g O}$ & $\mathbf{N a}_{2} \mathbf{O}$ & $\mathbf{S i O}_{2}$ \\
\hline 1 & 267 & 0,26 & 0,03 & 45,7 & 0,26 & 0,19 & 0,81 & 1,36 & 1,19 & 3,98 & 0,43 & 0,45 & 0,74 & 44,6 \\
2 & 343 & 1,16 & 0,08 & 7,45 & 8,32 & 0,54 & 0,23 & 3,08 & 4,15 & 5,77 & 1,45 & 2,87 & 8,33 & 56,6 \\
3 & 1386 & 0,014 & 0,02 & 44,9 & 0,0083 & 0,25 & 0,19 & 1,12 & 5,07 & 4,35 & 0,25 & 0,61 & 0,43 & 42,7 \\
\hline
\end{tabular}

Table 3. Concentration of trace elements in ppm determined by method of the emission spectroscopy

\begin{tabular}{llllllllllll}
\hline № & Element & $\mathbf{A g}$ & $\mathbf{A s}$ & $\mathbf{B}$ & $\mathbf{B a}$ & $\mathbf{B e}$ & $\mathbf{B i}$ & $\mathbf{C o}$ & $\mathbf{C r}$ & $\mathbf{G a}$ & $\mathbf{L i}$ \\
\hline 1 & $\mathbf{2 6 7}$ & 1,8 & 21 & 480 & 2200 & 2,5 & 3,1 & 31 & 84 & 12 & 27 \\
2 & $\mathbf{3 4 3}$ & 12 & 32 & 15 & 3850 & 2,9 & 1,9 & 190 & 1400 & 15 & 47 \\
3 & $\mathbf{1 3 8 6}$ & 1,6 & 12 & 640 & 2700 & 3,1 & 0,42 & 110 & 890 & 15 & 28 \\
& Element & $\mathbf{N b}$ & $\mathbf{N i}$ & $\mathbf{S b}$ & $\mathbf{S c}$ & $\mathbf{S r}$ & $\mathbf{V}$ & $\mathbf{Y}$ & $\mathbf{Y b}$ & $\mathbf{Z n}$ & $\mathbf{Z r}$ \\
1 & $\mathbf{2 6 7}$ & 8,9 & 11 & 210 & 9,2 & 78 & 140 & 32 & 3,9 & 41 & 210 \\
2 & $\mathbf{3 4 3}$ & 17 & 31 & 99 & 17 & 490 & 130 & 34 & 3,5 & 50 & 140 \\
3 & $\mathbf{1 3 8 6}$ & 14 & 310 & 35 & 6,4 & 71 & 130 & 31 & 3,1 & 49 & 170 \\
\hline
\end{tabular}

Let us consider the obtained data on a chemical composition of the studied samples glaze. Samples № 267 and № 1386 have the Si-Pb glaze and they are very similar by content of macro - and micro-elements. It may be concluded that ceramics is made by the technology of the same ceramic school. However, if we pay attention to the content of such micro-elements as $\mathrm{Bi}$ and $\mathrm{Co}$, we will find a great difference in concentration. It is known that cobalt is added to glass (glaze) as a dye, but, in our case, its content is far fewer than it is necessary for receiving the effect of coloring. The content of tin and iron is also very different. If the presence of various concentration of iron can be explained by the technology of coloring, tin, in this case, acts only as impurity probably to lead. Thus, we can conclude that pottery of type 1 and type 2 of white ware is made in different workshops though the technology of their production was identical. 
The sample № 343 has $\mathrm{Si}$ : $(\mathrm{Pb}+\mathrm{Sn})$ : Na glaze and the total content of lead and tin is about $16 \%$. It is obvious that in this case we are dealing with a product of other ceramic school. The high concentration of copper equal to $1,16 \%$ defines blue coloring of a sample.

\subsection{Comparative Analysis of Analytical Methods}

It was necessary to separate $50 \mathrm{mg}$ of the glaze from the ceramics for the emission spectral analysis. This factor is the most negative because it leads to violation of integrity of a sample. However, taking into account the low cost of the analysis, also from the standpoint of reliability, sensitivity and multiunit definitions, this method is rather attractive for the study of archaeological artifacts in that case when inconsiderable selection of a sample is allowed. The selection of samples is also made for the method of electron microscopy; however, in this case the microquantity which does not damage an artifact in general is enough.

The analysis of a glaze surface by the method of scanning electron microscopy revealed one more substantial defect of researches by this method. In spite of the fact that samples were carefully cleared, scanning surface only introduces an error into the determination of true content of elements. It is possible to pass over essential flaws which are always present at glazed ceramics, especially on archaeological samples, while choosing the analyzed area, so the distortions in values of components content brought by microflaws can not be considered. As it was already stated above, the carried-out X-ray phase analysis showed that glaze is an amorphous formation, i.e. all components of glaze in the course of burning were fused. It means that carbon can not essentially be present at such quantities as at any well melted glass (the standard in table 1). It is obvious that metamorphic changes of glaze occured in these microflaws. Therefore, these microflaws with their unknown content explain the essential concentration of carbon, phosphorus and chlorine, also discrepancy of research results by two methods on some components is given in table 1 . The concentration of elements is not counted for oxides intentionally as it is not known what entities were formed as a result of metamorphic changes of a glaze surface. As can be seen, basic elements of «washing out» are silicon and, perhaps, lead (tab.2, the 3rd sample № 267).

However, according to the table 1, the contents of many defined elements which make up glaze, received by both methods, are accurately correlated. A positive factor of electron microscopy is the possibility of determination of sulfur, fluorine and chlorine, as by method of emission spectroscopy determination of these elements is essentially possible, but is very difficult and time-consuming. However, it is necessary to consider that fact when melting glass and glaze these elements are almost completely evaporated and, thus, determining these components is not overriding necessity. At the same time in results of electron microscopy there is no wide range of elements which contents are significant. Especially it concerns such components as tin, lead, copper, etc, which are important for technology of glassmaking. Perhaps, lack of these elements is in this case a consequence of their complete "washing out" from a surface in the course of a metamorfization, but the most probable explanation, apparently, is low sensitivity of a method.

As already stated above, sensitivity of X-ray fluorescence method, apparently, sufficiently depends on the size of the studied surface. Taking into account that this size is rather small, there is one more negative factor of research. It is well-known that even thorough mixing of glaze components does not provide equal distribution of these components on a surface. Thus, the so-called error of "mixing" in case of the analysis by any method which strongly limits the surface size can significantly distort the actual content of certain elements. The arising question of significance of the sizes of the studied area remains unclear because all types of microprobe analysis methods of a chemical composition with the use of electronic microscope are very expensive. It is impossible to carry out statistical processing for detection of errors at the moment. By comparison, the sample which surface size is equal to $10-50 \mathrm{~mm}^{2}$ is taken for research by method of emission spectroscopy and if to consider the depth of penetration of an X-ray beam, significance of a sample weight in this case is 1000 times more.

It should be noted that there is also one more significant negative aspect of all modern analytical methods which results are interpreted and recounted by means of mathematical computer programs. The fact is that these programs provide automatic recalculation of the received concentrations for $100 \%$ (tab. 1). In case when some elements were not defined by the device, the lack of concentration of these elements is recalculated to another one. So it increases artificially the content of the elements determined by the device. By the so-called traditional "wet chemistry" analysis each element is determined separately, and in case when total concentration does not exceed $100 \%$, additional researches are carried out. "Loss" of the determined elements is essentially impossible by carrying out the analysis by emission spectroscopy method because the received spectrographs give information almost by all elements. The exceptions are $\mathrm{S}, \mathrm{F}$ and $\mathrm{Cl}$, however, as it was noted above, these components are evaporated when making glass and glaze. 
However, a very important advantage of studying archaeological artifacts by the method of electron microscopy is the minimum quantity of a sample which can be researched. It is the significative and indisputable advantage when we are dealing with the most valuable and rare finds; therefore, absolute exclusion of this method from the list for the study of archaeological objects seems to us unreasonable.

\section{Discussions}

Completing the overview of the studied classes of glazed ceramics from the excavation of the Kazan Kremlin, we will consider problems of their chronology and origin.

Mapping of finds through the Kazan Kremlin territory allows us to reveal places of concentration of similar glazed ceramics. 52 samples from total number come from excavations at the Khansky yard. Their concentration in this area means that exactly representatives of Khansky administrations were the main consumers of this production.

48 fragments from total number are connected with the period of the Kazan Khanate. There are 5 fragments from the late period of the Golden Horde. The rest of finds has no stratigraphic referencing or is derived. The ratio of products from the processed beddings most likely assumes their penetration from layers of Khanate period.

Conclusions can be made on the basis of comparison of the received results by a chemical composition of ceramics glazes from the Kazan Kremlin excavations with quantitative results of other researchers. The sample №343 has a lead-tin component as a basis. The content of basic elements which were determined by an X-ray spectral local method is brought in work by V.Yu.Koval' (2006). Based on the table data, our sample is similar to samples № 8, №10 and №85 by the glaze composition. These are samples of ceramics from composite white frit material of Iran of the XIII-XIV centuries (finds from Nizhny Novgorod and Vladimir) and pseudoceladon of the Golden Horde of the XIV century (the Selitrenny ancient settlement). It should be noted that Iranian glaze is distinguished by lead-tin mix, and there is no correlated regularity between the contents of these two elements. This can be explained by their use of raw materials comprising both lead and tin as a technological component at production of glaze on the Iranian technology. The sample of the Kremlin ceramics differs from the above-stated only by the high concentration of copper which acts as blue colorant.

Referring to results of the chemical analysis on determination of glaze composition, samples №267 and №1386 have absolutely identical contents with samples which were analyzed in the work by V. V. Bulgakov (2006). This work is devoted to studying the North Black Sea glazed ceramics of the XIII-XV centuries which was made in such large ceramic centers as Chersonese, Sudak, Solkhat and Kafa. According to the results of these analyses, Crimean glazed ceramics has the glaze similar to the Kazan samples, the $\mathrm{Si}$ : Pb type with the low content of other macrocomponents. Thus, it can be assumed that the part of ceramic ware from the Kazan Kremlin was made by the Crimean technology.

Samples which are similar to white ware with green glaze according to publications and reports were found at Kamayevsky, Arsky ancient settlements, Toretsky settlement. N.A. Kokorina (1991) calculated that at the Kamayevsky ancient settlement similar ceramics makes $10,5-11 \%$ of total number of ceramics (the general collection of ceramics is 7,5 thousand fragments). She refers it to local group of products, based on finds from a pottery workshop of the XIV-XVI centuries in the Russian-Urmatsky settlement. Pieces of engobed vessels, materials of excavation of pottery horns, remains of oven supplies on production of glazed ceramics were found by A. G. Mukhamadeev (1977). According to the typology of the Kamayevsky ancient settlement, similar ware belongs to subgroup of I-2 type 15 and is defined as of early Kazan period. Frequence of forms of not glazed ware in glazed products with preservation of local traditions of production is noted in this subgroup. According to Kokorina, an origin of this ceramics can be connected with Central Asia and with penetration into the Kazan Khanate of potter's experience from Khoresm, Otrar and the southern centers of the Golden Horde (Kokorina, Fakhrutdtnov, 1999). Based on materials of excavation from other regions, the similar ceramics is available in synchronous to the Kazan Kremlin layers of Moscow and Tver (Khokhlov, 2007).

According to the materials of the Kamayevsky ancient settlement and Russian-Urmastky settlement, appearance of white ware with brown glaze is linked with the second half of the XV century. It is probably presented by a small group, which explains the lack of mentioning its quantitative ratio with other groups of ceramics. R.G.Fakhrutdinov, (1973) connects its appearance in the middle of the XV century with the southern regions of the Golden Horde. Thereafter its production is continued. The chronology of its existing at these monuments coincides with supervision at the territory of the Kazan Kremlin.

\section{Conclusion}

Based on the presented analysis, the assumption of N. A. Kokorina and R.G.Fakhrutdinov (1999) of local 
production of white and red ware with green and brown glaze is rather thorough and confirmed by materials of the Kazan Kremlin. Sources of this glazed ceramics probably should be looked for in Central Asia and southern regions of the Golden Horde. Addressing to analogies it is also necessary to note that the products similar to artifacts from excavations of the Kazan Kremlin are found in numbers on the monuments of the Golden Horde Volga-Kama regions (the Kamayevsky ancient settlement, Russian-Urmatsky and Toretsky settlements).

It is obvious that analytical researches of other types of glaze, the paste of all the glazed ceramics will allow us to study the production technology in more detail and find the ceramic school of these finds. For this purpose there is a need for research of much wider number of samples from monuments at which the similar ceramics was found. The category of red ware with the blue glaze demands additional researches and search of analogies. A large number of these groups of glazed material in layers of the Kazan Khanate is the evidence of the trade center transition to Kazan as a result of the Lower Volga cities crash. And, perhaps, the own production of glazed ceramics is established here. Authors hope that further researches will give the chance to define precisely all characteristics of similar ceramics and to draw final conclusions about its origin.

\section{Acknowledgments}

This work was funded by the subsidy allocated to Kazan Federal University for the state assignment in the sphere of scientific activities.

\section{References}

Bachmatova, V., Khramchenkova, R., \& Sitdikov, A. (2013). Iterdisciplinary Research of Ceramics and Sources of Ceramic Production of the Volga Bulgaria in $13^{\text {th }}-14^{\text {th }}$ Centuries». Proceedings of $12^{\text {th }}$ Europian Meeting on Anciant Ceramics (180). Padova, Italy.

Bulgakov, V. V. (2005). Glazuri severo- prichernomorskoj polivnoj keramiki XIII-XV vv. Sbornik nauchnyh trudov, 1, 359-378.

Fahrutdinov, R. G. (1973) Zadachi arheologicheskogo izuchenija Kazanskogo hanstva. Sovetskaja arheologija, 4, 113-122.

Fernandez-Ruiz, R., \& Garcia-Heras, M. (2007). Study of archaeological ceramics by total-reflection X-ray fluorenscence spectrometry: Semi-quantitative approach. Spectrochimica Acta Part B, 62, 1123-1129. http://dx.doi.org/10.1016/j.sab.2007.06.015

Griffits D. (1999). The role of interdisciplinary science in the study of ancient pottery. Interdisciplinary science reviews, 24(4), 289-300. http://dx.doi.org/10.1179/030801899678957

Ionescu, C., Hoeck, V., \& Ghergari, L. (2011). Electron microprobe analysis of ancient ceramics: A case study from Romania. Applied clay science, 53, 466-475. http://dx.doi.org/10.1016/j.clay.2010.09.009

Kalinin, N. F. (1953). Otchet o raskopkah Kazanskogo kremlja v 1953 g. Otdel polevyh issledovanij Rossijskoj Akademii Nauk, R-1, 813, 112

Kalinin, N. F. (1954). Materialy arheologicheskih raskopok u Tajnickoj bashni Kazanskogo kremlja v 1954 g. Arhiv Instituta Jazyka i Literatury, fond 8, otdelenie 1, edinica hranenija 313, 94.

Kalinin, N. F. (1958). Istorija Kazani s drevnejshih vremen do XVI v. Rukopis' doktorskoj dissertacii. Arhiv Instituta Jazyka i Literatury, fond 8, otdelenie 1, edinica hranenija 202, 226-227.

Khalikov, A. Kh. (1985). Raboty v Kazani. Arheologicheskij otchet. Moskva.

Khalikov, A. Kh. (1989). Arheologicheskie nabljudenija na predbulachnoj chasti posada Kazani XV-XVI vekov. Arheologicheskie otkrytija Urala i Povolzh'ja. Syktyvkar.

Khalikov, A. Kh., Muhamadiev, A. G., \& Shavohin, L. S. (1976). Raskopki v Kazanskom Kremle. Arheologicheskij otchet. Moskva.

Khohlova, A. N. (2007). Stolovaja keramicheskaja posuda s sjuzhetnymi klejmami iz Tveri na fone vostochnoj keramicheskoj tradicii. Materialy mezhdunarodnoj nauchnoj konferencii «Srednevekovaja Rus', Volzhskaja Bulgarija i Severnoe Prichernomor'e v kontekste russko-vostochnyh svjazej». Kazan.

Khramchenkova, R. (2013). Elemental Analyses of Medieval Oriental Glaze Pottery. Proceedings of $12^{\text {th }}$ European Meeting on Ancient Ceramics (94). Padova, Italy.

Khramchenkova, R. Kh. (2011). Sravnitel'nyj analiz jelementnogo sostava glazurej srednevekovoj polivnoj keramiki. Arheologija i estestvennye nauki Tatarstana. Kazan': Izdatel'stvo Instituta istorii Akademii Nauk Respubliki Tatarstan. 
Khramchenkova, R., \& Sitdikov, A. (2014). Origin of glazed ceramics Kazan Kremlin: Cremia - Bulgaria Kazan. Conference proceeding SGEM 2014 (391-398) KU Leuven, Belgium. http://dx.doi.org/10.5593/sgemsocial2014/b31/s9.050

Kokorina, N. A. (1995) Keramika Kamaevskogo gorodishha (kul'turno-hronologicheskoe sootnoshenie). Zakazan'e: problemy istorii i kul'tury. Kazan, 28-32.

Kokorina, N. A. (1999). Keramika usad'by gonchara iz Iski Kazani. Tatarskaja Arheologija, 1-2, 70-71.

Kokorina, N. A., \& Fahrutdinov, R. G. (1999). Goncharnyj kompleks zolotoordynskogo perioda iz Iski Kazani. Tatarskaja Arheologija, 1-2, 103-134.

Koval', V. Ju. (2006). Vostochnaja polivnaja keramika iz raskopok Kazani. Kazan'v srednie veka i ranee novoe vremja. Materialy Vserossijskoj nauchnoj konferencii. Kazan.

Koval', V. Ju. (2009). Himicheskij sostav glazurej srednevekovyh fajansov. Donskie drevnosti, vypusk, 10, 209-237.

Muhamadiev, A. G., \& Fahrutdinov, R. G. (1977). Raskopki v Iski Kazani. Arheologicheskie otkrytija. Moskva.

Nuretdinova, A. R., \& Khramchenkova, R. Kh. (2011). Himicheskij sostav sferokonicheskih sosudov Volskoj Bulgarii. Sledy vekov. Materialy Vserossijskoj nauchnoj konferencii «Aktual'nye problemy arheologii Povolzh'ja i Priural'ja, posvjashhennoj 65-letiju arheologicheskogo kruzhka Kazanskogo universiteta (66-72). Kazan.

Shavohin, L. S. (1978). Raskopki v Zilantovom monastyre i Kremle goroda Kazani. Arheologicheskij otchet 1977. Moskva.

Shavohin, L. S. (1981). Arhitekturno-arheologicheskie raskopki v Kazani i Sivjazhske. Arheologicheskij otchet 1980. Moskva.

Shavohin, L. S. (1988). Srednevekovaja Kazan' dorusskogo vremeni v istoriko-ar $\neg$ heologicheskom otnoshenii. Dissertacija na soiskanie uchenoj stepeni kandidata istoricheskih nauk. Kazan'. Na pravah rukopisi. Nauchnaja Biblioteka Moskovskogo gosudarstvennogo universiteta, 8158.

Sitdikov, A. G. (2006). Kazanskij Kreml': istoriko-arheologicheskoe issledovanie. Kazan.

\section{Copyrights}

Copyright for this article is retained by the author(s), with first publication rights granted to the journal.

This is an open-access article distributed under the terms and conditions of the Creative Commons Attribution license (http://creativecommons.org/licenses/by/3.0/). 